\title{
Penanaman Nilai-Nilai Karakter pada Anak Panti Asuhan Melalui Pohon Cita-Cita
}

\author{
Martini $^{\mathrm{a}, 1}$, Ratika Nengsih ${ }^{\mathrm{a}, 2}$ \\ ${ }^{a}$ Dosen Tetap Universitas Muslim Indonesia \\ ${ }^{1}$ martini.halim@umi.ac.id, ${ }^{2}$ ratika.nengsi@umi.ac.id
}

\begin{abstract}
Abstrak
Dunia bermain setiap anak sangat ditentukan oleh cita-citanya. Pohon cita-cita anak memiliki gambaran keunikan berkeinginan untuk menjadi orang yan berguna dan penuh makna dalam hidupnya dimasa akan datang, namun seiring dengan berjalannya waktu, terkadang situasi dan kondisi membuat anak tersebut kehilangan harapan untuk meraih apa yang diinginkan, hal ini dipengaruhi oleh factor internal dan eksternal. Keadaan ini harus menjadi acuan bagi para pihak yang terkait seperti orangtua, guru dan masyarakat sekitar. Hal-hal yang dikhawatirkan terjadi adalah bukan hanya berkaitan pada diri pribadi anak tapi hal-hal yang akan ditimbulkan pada masyarakat, rekan anak lainnya. Sebagai bentuk kepedulian kepada anak maka peningkatan motivasi anak perlu diupayakan untuk membentuk integritas dan komitmen anak untuk sukses. Pengabdian kepada masyarakat melalui pohon cita-cita ini membantu anak untuk mengenal potensi dalam dirinya. Melalui pendidikan karakter adalah hal yang sangat penting, karena merupakan salah satu pendekatan yang mendasar dalam mendidik dan melahirkan peserta didik yang berjiwa Social dengan intelektual yang tinggi. Pengabdian yang dilaksanakan ini merubah mindset yang melahirkan suatu kemauan untuk melakukan perubahan dalam dirinya dengan tujuan untuk menjadi orang yang berguna rahmatan lil alamin. Kesadaran merubah mindset dan menuntut ilmu Pendidikan dalam rangka meraih apa yang dicita-citakan khususnya pada anak yatim piatu di Panti Asuhan Waturua Timor Timur Kecamatan Manggala Antang Kota Makassar.
\end{abstract}

Kata kunci: Penanaman Nilai; Pohon cita-cita; Nilai-nilai karakter

\section{Pendahuluan}

\subsection{Analisis Situasi}

Anak-anak pada umumnya memiliki keinginan besar tentang apa yang mereka raih untuk masa depannya. Setiap anak memiliki hak untuk menentukan apa yang ingin dia raih dalam hidupnya, orang tua, guru dan masyarakat berkewajiban untuk mendampingi anak dalam melaksanakan kegaiatan pembelajaran baik formal dan nonformal. Keinginan itu di awali dari motivasi yang dimiliki oleh anak, menuntun anak adalah salah satu bentuk tanggung jawab sebagai orang tua. Untuk mencapai tujuan itu tentu kita harus mempersiapkan dan memenuhi kebutuhan dari si anak akan ruang bagi anak untuk dapat mengekspresikan bakat-bakatnya. Dengan itu kita bias melihat ke arah mana minat anak-anak. Dengan memiliki cita-cita sejak dini tentu hal itu akan berdampak positive bagi perkembangan kecerdasan sang buah hati kita tersebut.

Panti Asuhan Waturua Timor Timur adalah mitra pengabdian yang mengasuh ratusan anak panti asuhan yang di dominasi oleh anak yatim piatu yang berasal dari Maluku, juga mengasuh anak khusus muallaf. Panti Asuhan sebagai salah satu wadah social masyarakat yang mengembangkan kemandirian anak, khususnya anak yatim piatu. Kemandirian merupakan salah satu aspek yang mempunyai pengaruh yang besar di masa depan anak. Sifat kemandirian apa bila tidak direspon dengan secara tepat dapat menimbulkan dampak yang merugikan bagi perkembangan psikologi anak. Karena pada saat itu anak sedang mencari jati diri mereka, maka orang tua harus memberikan bimbingan dan arahan kepada anak untuk mempersiapkan anak mengarungi kehidupan di masa mendatang.

Keluarga adalah agen pembimbing pertama dan utama, melalui keluarga anak pertama kali memperoleh dasar-dasar Pendidikan untuk menanamkan kemandirian dalam dirinya yang penting bagi pribadi maupun psikologi anak. 
Panti asuhan Yayasan waturua timor-timur awalnya adalah inisiatif dari sepasang suami isteri yaitu Ibu Nikhmah, S.Pd.I yang menikah dengan Patricio Da Silva yang merupakan mantan tentanra dari Timor Leste yang menjadi muallaf dan menjadi muslim serta keinginan besar untuk mempelajari Islam. Melihat banyak nya anak dan masyarakat lainnya yang ingin mengikuti jejaknya untuk memeluk Islam maka beliau menampung beberapa orang dikediaman beliau untuk secara Bersama-sama belajar tentang agama Islam. Akan tetapi kondisi masyarakat yang didominasi oleh masyarakat yang beragama katolik menjadikan mereka kelompok muslim jumlah kecil di Timor Leste, sehingga hijrah merantau ke Maluku dan menampung lebih banyak anak dan masyarakat yang memeluk Islam. Untuk membuat para muallaf jauh dari kondisi masyarakat yang mayoritas katolik dan kebiasaan-kebiasaan masyarakat lainnya maka untuk menghindari para muallaf yang tinggal dikediaman beliau lebih focus untuk belajar makan Patricio Da Silva memutuskan untuk hijrah merantau ke Tanah Sulawesi Selatan tepatnya di makassar dan menempati rumah kontrakan yang sederhana, hingga tinggal di kolong rumah warga yang memiliki lahan kosong. Hingga saat ini diawal bulan September 2019 setelah dana yang dikumpulkan cukup untuk membeli tanah maka belaiu memutuskan untuk membeli dan membangun tempat tinggal sederhana bagi para anak yatim dan muallaf untuk tinggal.

Karakter-karakter universal itu diharapkan mampu menjadi bekal menadi manusia yang membawa kemanfaatan besar bagi lingkungan. Selain itu, pohon cita-cita juga memiliki dampak positif bagi lingkungan secara langsung, karena pohon-pohon yang nantinya ditanam oleh siswasiswi dapat mendukung penghijauan di lingkungan sekitar.

Program ini mempunyai tujuan jangka panjang untuk mencetak generasi yang peduli terhadap lingkungan dan berkarakter "beintegritas dengan cita0cita yang ingin diraih". Tujuan khusus dari program ini adalah alternatif metode pendidikan karakter "sisdarling" pada anak-anak. Manfaaat dari Pohon Cita-Cita ini dapat dirasakan oleh banyak pihak. Bagi naka yatim tentunya mampu menumbuhkan karakter - karakter positif dan menanamkan rasa cinta terhadap lingkungan.Program ini juga mempunyai keberlanjutannya.

\section{Solusi Dan Target Luaran}

\subsection{Solusi}

Luaran dan solusi yang ditawarkan dalam menyelesaikan permasalahan yang ada di Panti Asuhan Yayasan Islam Waturua Timor Timur Antang Kota Makassar terkait dengan pengabdian yang akan dilakukan adalah:

a. Membentuk karakter Islami anak Panti asuhan Yayasan Islam Waturua Timor Timur melalui penanaman karakter dengan pohon cita-cita.

b. Memberikan pendampingan pembuatan keterampilan dalam membuat pohon cita-cita yang menggambarkan nilai-nilai karakter Islami

c. Menghasilkan kreatifitas anak dalam membuat pohon cita-cita.

\subsection{Target Luaran}

a. Semua anak-anak di panti asuhan karakter Islami

b. Anak-anak pani asuhan memiliki cita-cita impian

c. Anak-anak mampu merangkai kreativitas tangan pohon cita-cita

d. Melakukan prosiding dalam bentuk seminar

e. Publikasi media on line

f. Membentuk masyarakat sebagai mitra dan memberdayakan masyarakat sesuai dengan metode ini.

\section{Metode Pelaksanaan}

Metode yang akan dilakukan dalam pengajaran Panti Asuhan Yayasan Islam Waturua Timor Timur dibagi dalam beberapa tahap, yaitu : 


\subsection{Sosialisasi}

Pada tahap awal dalam pengajaran di Yayasan Islam Waturua Timor Timur ini, akan dilaksanakan sosialisasi kepada masyarakat sasaran yang akan mendapatkan pendidikan Al Qur'an sebagai sumber pengajaran nilai-nilai karekter dan untuk mensosialisasikan gerakan siswa sadar lingkungan. Sosialisasi ini bertujuan untuk menarik minat sasaran untuk belajar dan sadar akan lingkungan.

\subsection{Persiapan}

Melanjutkan dari tahapan sebelumnya akan dilaksanakan persiapan dimana pengabdiakan menyiapkan konsep berupa buku modul dan alat, bahan dan media yang digunakan dan diperlukan dalam pembuatan Pohon Cita-cita yang akan terdiri dari rangkaian dahan yang mengandung kata Asmaul Husna yang akan diuraikan dengan bersinergi dengan karakter anak yang menjaga lingkungan sebagai wujud pelaksanaan dengan Gerakan Sisdarling.

\subsection{Pelaksanaan Program}

Program ini dilaksanakan dalam 3 kali pertemuan di TPA Panti Asuhan Yayasan Islam Waturua Timor Timur Antang Kota Makassar. Setiap pekan akan dilaksanakan 1 kali pertemuan yang melalui beberapa tahap kegiatan, yaitu :

1. Mengidentifikasi sistuasi dan kondisi anak-anak yatim piatu mulai dari kebiasaan, kegiatan dan kebutuhan

2. Membagi kelompok anak-anak yatim yang berpartisipasi

3. Setiap kelompok akan diajar oleh 1 orang pengajar dalam bentuk halaqah (lingkaran) belajar sambal bermain

4. Merangkai Pohon Cita-Cita

\subsubsection{Metode pembelajaran}

a. Metode observasi adalah metode pengumpulan data dengan mengamati secara langsung di lapangan. Metode ini digunakan sebagai penunjang atau pelengkap dengan sasaran para tenaga pengajar dan anak yatim piatu ,yakni pada penerapan metode Instruksional dan tanya jawab dalam kegiatan pembelajaran.

b. Metode selanjutnya adalah learning is fun memberikan pengajaran dengan cara belajar dengan bermain

c. Metode picture and picture mensosialisasikan gerakan siswa sadar lingkungan dengan gambar yang dirangkum dalam pohon cita-cita

d. Metode lainnya adalah pemberian games di sela-sela pelaksnaan pembelajaran

\subsection{Evaluasi}

Pertemuan dilaksanakan selama 3x dilaksanakan pada pekan-pekan yang telah ditentukan akan diadakan evaluasi untuk mengetahui tingkat kemampuan anak dalam memahami dan mengaplikasikan gerakan sisdarling dan mengobservasi sejauh mana perubahan sifat dan kebiasaan anak yang ikut berpartisipasi. Evaluasi diadakan dengan tujuan untuk membahas setiap keluhan yang dihadapi dalam tiap unitnya dan mencari solusi agar masyarakat yang berpartisapasi mendapatkan ilmu secara maksimal sebelum pindah ke unit selanjutnya.

\section{Pembahasan}

\subsection{Bentuk, Waktu dan Tempat Kegiatan}

Dalam melaksanakan pengabdian kepada masyarakat ini secara sistematis direncanakan untuk lebih mengarahkan tujuan pengabdian secara sistematis. Sebelum kegiatan pelatihan penulisan karyta tulis ilmiah dilaksanakan, tim pelaksana melakukan rapat persiapan dan dilanjutkan dengan kunjungan ke lokasi mitra pengabdian. Kunjungan ini dilakukan dalam rangka melakukan survei pra-pelatihan. Di lokasi mitra, tim pelaksana menemui kepala sekolah Ibu untuk membicarakan bentuk kegiatan, waktu dan tempat kegiatan dilaksanakan, serta hal-hal penting lainnya, baik yang bersifat administratif maupun yang bersifat teknis. 
Setelah melakukan komunikasi dalam plaaning kegiatan masyarakat di mitra pengabdian yaitu di Pantiasuhan Waturua Timor Timur Antang Kota Makassar maka dari komunikasi dengan pihak mitra, diperoleh informasi mengenai data panti asuhan,sarana dan prasarana, jumlah anak dan keadaan panti asuhan juga kebutuhan lainnya yang diperlukan agar pelaksanaankegiatan pelatihan dapat berlajan dengan lancar. Selanjutnya, tim pelaksana menyiapkan administrasi persuratan, seperti surat izin pelaksanaan pengabdian dan surat tugas kepada anggota tim pengabdian masyarakat dari pejabat yang berwenang. Surat izin tersebut kemudian ditindak lanjuti Kepala Panti Asuhan.

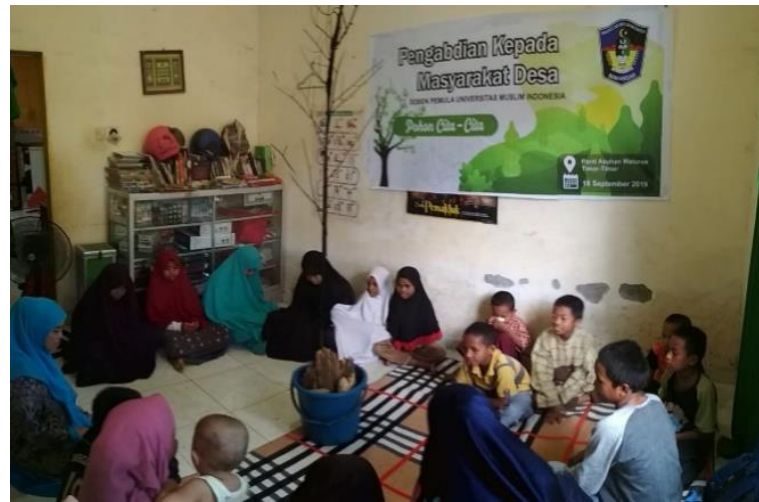

Gambar 1. Pembukaan

Pelaksanaan Pendampingan Pada Mitra Pengabdian Masyarakat

Jumlah informasi anak dan Pembina panti asuhan waturua timor timur menjad bahan untuk mempersiapkan kegiatan pendampingan dan penyuluhan pada anak yatim piatu. Hal-hal yang perlu dipersiapkan berkaitan dengan alat dan bahan adalah: kertas karton, HVS, pewarna, cat, pohon hias, gunting, seminar kit untuk Pembina, snak dan komsumsi makan siang, LCD, dan lain sebagainya.

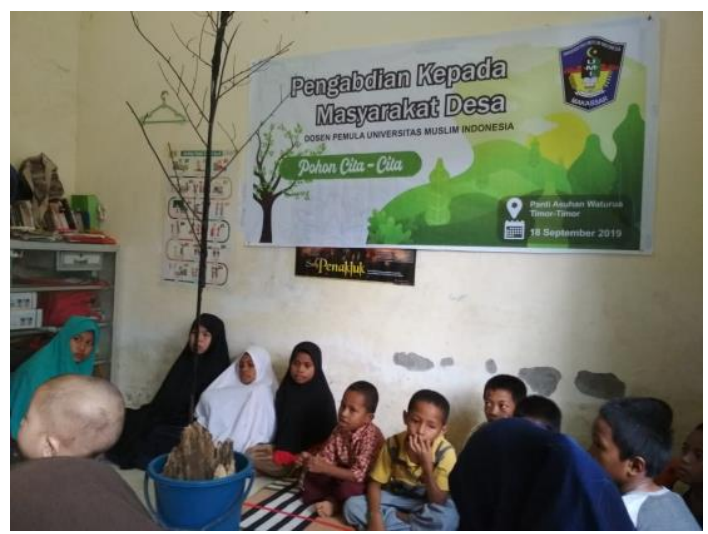

Gambar 2. Pertemuan I

Pelaksanaan Pendampingan Pada Mitra Pengabdian Masyarakat

\subsection{Bentuk Kegiatan}

Pelaksanaan kegiatan pengabdian kepada masyarakat ini merupakan aplikasi dari ilmu dan pelaksanaan kewajiban tri darma perguruan tinggi selaku dosen di universitas muslim Indonesia. Kegiatan yang dilakukan adalah bentuk pendampingan dan penyuluhan yang bertujuan mendampingi para Pembina untuk mampu meningkatkan kembali motivasi belajar anak yatim piatu agar memiliki semangat dalam menggapai cita-cita meski dengan ketiadaan orang tua lagi yamng mendampingi anak-anak. Peran itu digantikan oleh para pembiona yang ada di panti asuhan Waturua timor timur, jumlah anak yang ada di panti asuhan adalah 112 anak yang tergabung sebagai anak yang berstatus keluarga yatim piatu dan sebahagian lainnya adalah anak yangb berasalh dari Kupang akan tetapi baru masuk Islam dan menjadi Muslim (Muallaf), karena kondisi masyarakat di sana yang didominasi oleh masyarakat yang beragama Katolik dan minimnya tempat mengkaji agama di sana. Maka anak tersebutb dibina di panti asuhan waturua timor timur 
manggala Antang kota makassar. Kegiatan ini bertujuan untuk membentuk karakter anak untuk lebih optimis dan berkarakter, hal itu mampu membentuk keinginan anak untuk meraih keinginan terbesar dalam hidupnya, hal yang selama ini menjadi kesulitan bagi para Pembina adalah anakanak yatim piatu yang kurang memiliki semangat untuk meraih masa depan dikarenakan status yatim piatu sehingga proses pembinaan kurang berjalan secara maksimal, ditambah lagi dengan hal yang dialami anak di sekolah pada umumnya adalah Bulliying oleh rekan sebaya di sekolah karena status tersebut, sehingga para pengabdi berinisiatif untuk membuat kegiatan pendampingan melalui pohon cita-cita dalam membentuk karakter anak di panti asuhan waturua timor-timur.

\subsection{Waktu dan Tempat Kegiatan}

Pendampingan Pembentukan Karakter anak panti asuhan melalui pohon cita-cita dilaksanakan 2 x selain saat melakukan komunikasi dan observasi awal di Pant Asuhan Waturuan Timor Timur Makassar.pendampingan ini dilaksanakan pada tanggal 10 september pada pertemuan pertama dan 18 september untuk pertemuan ke dua dan dihadiri oleh para Pembina serta anak-anak panti asuhan waturua timor timur makassar. Secara rinci, jadwal dan pendampingan pembinaan karakter melalui pohon cita-cita dapat dilihat pada pada Tabel 5.1 berikut:

Tabel 5.1 Nama Pembina dan anak panti asuhan waturua timor timur makassar

\begin{tabular}{|c|c|c|}
\hline No. & Nama Guru & Jabatan \\
\hline 1. & Syamsuddin Hornai,S.Pd.I. & Pimpinan Panti Asuhan \\
\hline 2. & Nikhmah,S.Pd.I. & Bendahara \\
\hline 3. & Salma De Carvo & Pembina \\
\hline 4. & Patricio Da Silva & Pembina \\
\hline 5. & Nur Ji'ah & Pembina \\
\hline 6. & Harun hamzah & Pembina \\
\hline 7. & Abdul Razak & Pembina \\
\hline 8. & Khoiriah & Pembina \\
\hline No. & Nama & Jenis kelamin \\
\hline 1. & Jihad & Laki-laki \\
\hline 2. & Aiman & Laki-laki \\
\hline 3. & Ridwan & Laki-laki \\
\hline 4. & Abdul Wahab & Laki-laki \\
\hline 5. & Kasmin & Laki-laki \\
\hline 6. & Hayati & Laki-laki \\
\hline 7. & Hafidz & Laki-laki \\
\hline 8. & Syaifa Da Costa & Perempuan \\
\hline 9. & Mardiyah & Perempuan \\
\hline 10. & Asiah & Perempuan \\
\hline 11. & Mu'minah & Perempuan \\
\hline 12. & Hamidah & Perempuan \\
\hline 13 & Rara & Perempuan \\
\hline 14 & Aisyah & Perempuan \\
\hline 15 & Arif & Laki-laki \\
\hline 16 & Ahmad & Laki-laki \\
\hline 17 & Rahma & Perempuan \\
\hline 18 & Nabila & Perempuan \\
\hline 19 & Wahyuni & Perempuan \\
\hline 20 & Zainab & Perempuan \\
\hline 21 & Mutmainnah & Perempuan \\
\hline 22 & Indah & Perempuan \\
\hline 23 & Nabila & Perempuan \\
\hline 24 & Salsabila & Perempuan \\
\hline 25 & Yeni & Perempuan \\
\hline 26 & Nikhmah basri & Perempuan \\
\hline
\end{tabular}




\begin{tabular}{|c|l|c|}
\hline 27 & Ikbal & Laki-laki \\
\hline 28 & Zainab & Perempuan \\
\hline 29 & Jupri & Laki-laki \\
\hline 30 & Sabar & Laki-laki \\
\hline 31 & Umar & Laki-laki \\
\hline 32 & Faith & Laki-laki \\
\hline 33 & Abdurrahman & Laki-laki \\
\hline
\end{tabular}

Identitas Pembina dan anak panti asuhan di panti asuhan Yayasan waturua timor timur di atas, beberapa diantaranya adalah nama yang telah berubah setelah memeluk agama Islam dan menjadi muslim. Jumlah keseluruhan peserta anak yatim piatu tidak secara keseluruhan mengikuti kegiatan pengabdian dikarenakan sekolah dan sebahagian membantu tukang yang sedang mengerjakan pembangunan Panti Asuhan.

Berikut akan diuraikan hasil evaluasi pelaksanaan pembinaan karakter anak panti asuhan melalui pohon cita-cita.

Dalam kegiatan ini motivasi belajar anak panti asuhan sudahn mengaami peningkatan hal tersebut dibuktikan dengan keaktifan anak dalam mengikuti pembinaan dan merangkai pohon citacita yang telah mereka tuliskan dan daun pohon cita-cita serta tanggapan tentang kegiatan ini, anak panti asuhan telah menyadari karakter yang harus dimiliki ketika ingin meraih cita-cita yang ingin digapai oleh setiap anak. Para Pembina telah menyadari kebutuhan psikis anak dalam belajar serta serta kebutuhan anak berupa perhatian lebih karena kondisi yang berbeda dengan anak pada umumnya, serta perbedaan budaya asal dengan rekan di sekolah.

\section{Hasil yang Dicapai}

Tujuan akhir dari kegiatan pengabdian kepada masyarakat ini adalah terbentuknya karakter anak panti asuhan yang secara sungguh-sungguh menyadari potensinya, dan memiliki kemamuan tinggi untukbelajar dan menetapkan apa yang mereka ingin raih di masa depan. Lainnya dalah memberikan pengetahuan dan kemampuan kepada para Pembina untuk memahami kondisi dan kebutuhan anak secara fisik dan psikis serta kebutuhan belajar mereka, hal itu dikarenakan karena status dan kondisi anak yang berbeda dengan anak lainnya baik dilingkungan tempat tinggal maupun di sekolah. Pemahaman keagamaan anak yang berada di panti asuhan waturua timor timur juga masih dalam tahapan dasar dikarenakan kebanyakan dari mereka adalah muallaf yang berasal dari timur Indonesia. Terlaksananya pengabdian ini oleh tim dari fakultas agama Islam universitas muslim Indonesia dan mahasiswa dari program studi yang ada di FAI UMI Makassar dilakukan secara Bersama-sama dan saling terintegrasi.

Kegiatan ini dibuka oleh pimpinan panti dan ketua tim pengabdian masyarakat internal serta tim pelaksana. dalam sambutannya saat membuka acara menyampaikan apresiasi dan penghargaannya kepada Universitas Muslim Indonesia, LPMD-UMI, para dosen dan mahasiswa, atas inisiatif dan kerja samanya yang semakin konstruktif dengan lembaga-lembaga. Setelah acara pelatihan dibuka secara resmi, kegiatan dilanjutkan dengan penyajian materi-materi. Para pemateri secara berurutan memaparkan materinya masing-masing, sesuai dengan susunan acara yang telah disusun. Pelaksanaan pelatihan dibagi menjadi 2 tahapan pertemuan, berikut adalah terlaksananya kegiatan pengabdian pada masyarakat dalam pembinaan karakter anak melalui pohon cita-cita.

\subsection{Evaluasi Kegaiatan}

Pelaksanaan pembinaan karakter dievaluasi berdasarkan taraf respons peserta mengenai kebermanfaatan kegiatan pelatihan yang telah diikuti. Data tersebut diperoleh dari hasil wawancara kepada peserta yang telah mengikuti pelatihan. Fakta yang terlihat selama kegiatan pelatihan berlangsung, para peserta tampak bersemangat memperhatikan materi yang disajikan. Selain itu, pada sesi Tanya jawab, beberapa peserta juga antusias memberikan pertanyaan dan tanggapan kepada pemateri. Dengan demikian, gambaran mengenai hal di atas dapat dikatakan bahwa pelaksanaan kegiatan pembinaan dapat meningkatkan kualitas pembinaan anak panti asuhan dan memberikan motivasi bagi anak di apanti asuhan waturua timor-timor. 


\section{Kesimpulan}

Penanaman nilai-nilai karakter anak panti asuhan Yayasan Waturua Timor Timur Antang kota Makassar melalui pohon cita-cita adalah salah satu bentuk Pendidikan non formal yang berorientasi pada pembentukan karakter anak. Pendampingan pembuatan pohon cita-cita merupakan media ekspresi dan kreasi yang mempunyai tujuan ganda yaitu tujuan pribadi dan tujuan masyarakat. Bertujuan pribadi karena penanaman nila-nilai karakter anak dalam pembuatan pohon cita-cita menggambarkan karakter anak itu sendiri yang bersifat unik. Dari keunikan individu dapat ditumbuh kembangkan yang berorientasi kepada kreativitas anak dalam membuat cita-citanya melalui pohon cita-cita anak itu sendiri (individu). Dalam tujuan masyarakat penanaman nilai karakter memiliki kekhususan dengan menggunakan dimensi ruang dan waktu. Keunikan nilai-nilai karakter pada anak panti asuhan Yayasan Waturua Timor Timur terletak pada dimensi estetik, dimensi ekspresif, dimensi inovatif, dan dimensi kreatif yang disentuh dengan nilai-nilai islami sehingga pemberian pengalaman emosi jiwa kepada peserta didik diberikan dalam bentuk kegiatan berekspresi/berkreasi dan berapresiasi melalui pendekatan penenaman nilai-nilai karakter melalui pohon cita-cita. 


\section{DAFTAR PUSTAKA}

Ahmadi Abu, Rohani Ahmad.. Bimbingan dan Konseling di Sekolah. Jakarta: PT. Rineka Cipta, 1991

Departemen Pendidikan dan Kebudayaan.. Kamus Besar Bahasa Indonesia. Jakarta: Balai Pustaka, 2013

Usman, Ahmad. Mari Belajar Meneliti.Jogjakarta : Genta Press, 2008

Agus Wibowo, Pendidikan Karakter: Strategi Membangun Karakter Bangsa Berperadaban (Yogyakarta: Pustaka Pelajar, 2012).

E. Mulyasa, Manajemen Pendidikan Karakter, (Ed.1.Cet. 3; Jakarta: Bumi Aksara, 2013), h. 9-10.

E. Mulyasa, Manajemen Pendidikan Karakter, (Ed.1.Cet. 3; Jakarta: Bumi Aksara, 2013), h. 9-10.

Fitriani Mangkuin, "Pengaruh Pendidikan Agama Islam terhadap Pembentukan Akhlak Siswa SMP Negeri 3 Samang Pulau-Pulau Aru Maluku". Skripsi. Makassar: Universitas Muslim Indonesia, 2017.

Haidar Putra Daulay, Pemberdayaan Pendidikan Agama Islam di Sekolah, (Cet. 1; Jakarta: Kencana, 2016).

Ika Malgi Ulfa, "Pengaruh Pendidikan Agama Islam terhadap Akhlak Siswa SD Islam AlMiftahul Diniyah di Kelurahan Pondok Cabe Udik". Skripsi. Jakarta: Universitas Islam Negeri Syarif Hidayatullah, 2010.

Muhammad Fauzi, Agama dan Realitas Sosial Renungan dan Jalan Menuju Kebahagiaan, (Cet. 1 Jakarta: PT Raja Grafindo Persada, 2007).

Syamsul Kurniawan, Pendidikan Karakter Konsep dan Implementasi secara Terpadu di Lingkungan Keluarga, Sekolah, PerguruanTinggi, dan Masyarakat.(Cet. III; ArRuzz Media, 2016). 